\title{
Studies on Free Radical Polymerizations by the Measurement of Kinetic Chain Lifetimes
}

\section{Effect of Carbon Tetrachloride on Styrene Polymerization}

\author{
By Saburō Fujii and Satohiro Tanaka
}

The average lifetimes of kinetic chains in the photo-polymerization of styrene with and without carbon tetrachloride have been measured, at various conversions, in order to find the factors of controlling chain termination. Under our experimental conditions, the photo-rate is found to be sensitized with carbon tetrachloride, and the low conversion results show a difference in $k_{p} / k_{t}$, the rate constant ratio of chain propagation to termination, between the unsensitized and sensitized systems. At high conversions, both the rate and the lifetime increase remarkably for the unsensitized system, while these increases are considerably diminished in the presence of carbon tetrachloride. Analysis of our data indicates the marked effect of bulk viscosity on the termination reaction and also suggests, under several assumptions, that the magnitude of $k_{t}$ at a given high viscosity depends on the chain-transfer probability of polystyrene radicals.

\section{䟓}

高分子化学, 13, No. 140 (1956) 呉祐吉, 鈴木恵著「織物の防䠊性について」第 2 報に誤りがありましたの で訂正いたします。

508 ページ 19 行目の「最大限は」とありますが，その「は」をとる。

509 ページ 30 行目の (2) 式中 $\cos ^{2} \psi / 2 G J$ は $\cos ^{2} \beta / 2 G J$ に, 次の行の $\sin ^{2} \beta / E I$ は $\sin ^{2} \beta / 2 E I$ 之訂正。

510 ページ 3 行目 (3) 式中 $\left.A=h_{0}{ }^{2} M^{2} \cdots \cdots \cos ^{2} \beta / 2 G J\right\}$ は $\left.A=h_{0} M^{2} \cdots \cdots \cos ^{2} \beta / 2 G I\right\}$ と訂正。

同ページ 16 行目 (8) 式中 $B=n \cdot B_{s}=E I$ は $B=n \cdot B_{s}+E I$ と訂正。

511 ページ 1 行目 $l_{0}=h_{0} / \sin \beta$ は $l=h_{0} / \sin \beta$ に, 2 行目 (10) 式中 $A=h_{0}{ }^{2} T^{2} \ldots \ldots$ は $A=h_{0} T^{2} \ldots \ldots$ と訂正。 512 ペーシ 16, 17 行目 (24)，(25) 式中カッコ内分母, $E+\left\{1+\frac{1}{1+\left(h_{0} / 2 \pi r\right)^{2}}\right\}$ は $E+\left\{\frac{1}{1+\left(h_{0} / 2 \pi r\right)^{2}}\right\}$ と 訂正。なお(25) 式中 $\sigma_{s}=d / Z R \cdot h_{0} \cdots \cdots$ は $\tau_{s}=d / 2 R$ と訂正。

昭和 32 年 2 月 20 日 印刷昭和 32 年 2 月 25 日 発行

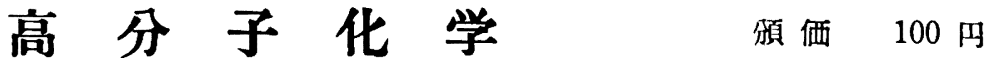

編集兼発行人荒肃溪吉 印刷所研究社印刷株式会社

発行所㼛団法人高分展学会 東京都中央区日本橋本町 3 の 9 緎維会館內 鼠話日本橋 (24) 2793 振替東京111688 